УДК 338.47:711.16 (477.74)

DOI 10.33082/2226-1893-2019-3-109-123

\title{
ПРОБЛЕМИ ТРАНСПОРТНОЇ ІНФРАСТРУКТУРИ ОДЕСИ ТА ПРОЕКТИ ДЛЯ ЇХ ВИРІШЕННЯ
}

\author{
О.О. Лапкін \\ зав. лабораторії кафедри «Менеджмент та маркетинг» \\ Одеський національний морський університет, Одеса, Украина
}

Анотація. В статті розглядаються основні проблеми транспортної інфраструктури Одеси, причини їх виникнення та наслідки. Головними є: недостатня кількість дорожніх об'єктів для здійснення зв'язку иентральної частини міста з мікрорайонами, недостатність магістралей, відсутність системи невуличного транспорту (у тому числі для забезпечення морських прибережних сполучень), чіткого призначення велодоріжок, проблеми парковок та ін. Розглядаються иілі проектів, спрямовані на поліпшення ситуащії, щзо склалася.

Ключові слова: транспортна інфраструктура, міський транспорт, морські прибережні сполучення.

УДК 338.47:711.16 (477.74)

DOI 10.33082/2226-1893-2019-3-109-123

\section{ПРОБЛЕМЫ ТРАНСПОРТНОЙ ИНФРАСТРУКТУРЫ ОДЕССЫ И ПРОЕКТЫ ИХ РЕШЕНИЯ}

\author{
А.А. Лапкин \\ зав. лабораторией кафедры «Менеджмент и маркетинг» \\ Одесский национальный морской университет, Одесса, Украина
}

Аннотация. В статье рассматриваются основные проблемь транспортной инфраструктуры Одессы, причины их возникновения и следствия. Основными являются: недостаточное количество дорожных объектов для связи центральной части города с микрорайонами, нехватка магистралей, отсутствие системы внеуличного транспорта (в том числе обеспечивающего морские прибрежные сообщения), отсутствие четкого назначения велодорожек, проблемы парковки и т.д. Рассматриваются иели проектов, направленные на улучшение сложившейся ситуаuุuu.

Ключевые слов: транспортная инфраструктура, городской транспорт, морские прибрежные сообщения.

(С Лапкін O.O., 2019 
UDC 338.47:711.16 (477.74)

DOI 10.33082/2226-1893-2019-3-109-123

\title{
TRANSPORT INFRASTRUCTURE PROBLEMS OF ODESSA AND PROJECTS FOR THEIR SOLUTION
}

\author{
O.O. Lapkin \\ Head of «Management and Marketing» Laboratory \\ Odessa National Maritime University, Odessa, Ukraine
}

\begin{abstract}
The article deals with the main transport infrastructure problems in the city of Odessa, the reasons for their occurrence and the consequences, considering the historical influence and the city's role in the state development. The main problems are: insufficient number of road facilities for communication between the Central Business District and peripheral microdistricts; parking problems; lacks of highways, off-street transport units, clear bicycle roads assignment and modern transport connections between the Central Business District, the International Odessa Airport and the Industrial Goods Market. The objectives of projects aimed at improving the situation are being considered. The main goals of them are: increasing the number of rational transport overpasses, highways, bridges, communication hubs; adequate legislative actions to enact laws and enforce liability for violations of traffic rules, as well as mechanisms for their implementation by local interior affairs authorities; bicycle roads extending and off-street transport growth. Due to the Odessa Bay geographical location, the restoration of the suburban marine passenger traffic routes will make sense. The city and the region further economical prosperity depends on the road quality, their traffic capacity, urban and tourists public transport convenience and comfort.
\end{abstract}

Keywords: transport infrastructure, urban transport, sea coastal communications.

Актуальність теми дослідження. Розвиток транспортної інфраструктури $є$ одним з найактуальніших питань міського життя. Відомо, що транспортна мережа будь-якого міста $є$ основою, навколо якої відбувається містобудування. В останні десятиліття транспортна інфраструктура Одеси розвивалася під впливом багатьох чинників. Слід, перш за все, відзначити наступне: відносна стійкість кількості населення міста (до 2001 р. - 1001 тис. осіб, 2005 р. - 989 тис. осіб, 2011р. - 991 тис. осіб, 2017 р. - 993 тис. осіб) [1]; зверх активний розвиток будівництва житла як в самому місті, та й в його найближчих передмістях («7 Небо», «Червоний Хутір», «Совіньон», ін.), а також у селищі Котовського, яке, хоча знаходиться в межах міста, але $\epsilon$ сильно віддаленим від центру як 
територі-ально, так і в транспортному сполученні; зміна структури зайнятості населення (за останні 25 років кількість робочих міст осіб, зайнятих в промисловому виробництві різко впала, а зайнятих у сфері послуг збільшилася і складає більш ніж 80 \%) [2]; зростання кількості автомобілів на душу населення міста від 75 од. на тисячу жителів у 1991 р. до 202 од. в 2013 р., а також щонайменше на $10 \%$ за останні два роки у зв'язку зі змінами в законодавстві [3; 4].

Таким чином, при здавалося б стабільній кількості жителів Одеси спостерігається активне збільшення території, освоєної для житла, зростання як середніх відстаней від місць масового нового будівництва до центральної частини міста, а також кардинальне збільшення забудованих площ у вже розвинених районах центральної частини міста. Це, одночасно зі змінами в структурі зайнятості та рівня достатку населення, яке проживає в новобудовах, призводить до додаткового збільшення мобільності населення в цілому, і особливо різко - в певних вузлах.

Аналіз досліджень і публікацій. Слід зазначити, що темпи розвитку вулично-дорожньої мережі в 2000-х рр. мали явний регресивний характер. Дорожні програми цього періоду в основному передбачали підтримання стану покриття проїзної частини i тротуарів в рамках існуючих норм тих реалій; були переглянути і перетворені напрямки транспортних потоків через основні вулиці міста шляхом зміни правил дорожнього руху (з одностороннім рухом, без поворотів тощо). Пропускна здатність вулиць при цьому практично не змінилася.

Морський пасажирський транспорт ближнього радіусу перевезень, якому у попередні часи приділялося достатньо уваги, як з боку сучасних для відповідного періоду технічних характеристик транспортних засобів, так і з боку організації міських перевезень [5-7], було вилучено $з$ життя міста і передано в категорію туристичних розваг. Таким чином, від основних транспортних вузлів за участю морського транспорту залишився лише основний - Морський вокзал, а решта були заморожені, орендовані або просто забуті.

Однак 3 початку 2010-х рр. з'явилися нові фінансові та інтелектуальні можливості розвитку транспортної інфраструктури. У цей час розпочалося практичне втілення двох великих дорожніх проектів: завдяки обміну досвідом з європейськими партнерами система маркування була радикально перероблена, а також максимально розширена доступна про-їжджа частина усіх доріг 3 високою інтенсивністю руху. Незважаючи на втілення таких сміливих рішень, щільність руху в межах міста, особливо в місцях концентрації будівництва нового житла, значно зросла.

32001 до 2019 рр. в Одесі було реалізовано лише кілька проектів для розвантаження автотранспортних магістралей. Так, наприклад, сильно завантажений «Горбатий міст» отримав односторонній рух і зворотний шлях, що проходить під залізничним полотном, і шляхопровід «Поїзний» 
[8]. На жаль, заходи, що було проведено, не змогли спричинити фундаментальний вплив на стан дорожньої ситуації у місті. Щільна забудова, висока вартість проектів і багато, здавалося б, виправданих будівельних рішень призвели до своєрідного переміщення транспортних проблем не так далеко від тих місць, які були визначені опорними для зменшення інтенсивності транспортних потоків.

Аналізуючи транспортну інфраструктуру Одеси, слід відзначити основні зміни, які відбулися в роботі громадського транспорту в місті за останні роки. По-перше, протягом багатьох десятиліть програма реновації міського транспорту провадилась слабо обгрунтованими діями та яскравими одиничними екземплярами, а не реальною зміною рухомого складу. По-друге, не реалізованими залишилися всі плани щодо розширення та оптимізації існуючих вуличних видів транспорту (швидкісний трамвай). По-третє, не ведеться робота зі створення альтернативних позавуличних видів транспорту (монорейка, «морські трамваї»). Почетверте, завдяки збільшенню кількості автомобілів і необхідності їх паркування, вся робота з розширення і оптимізації дорожньої ділянки за рахунок тротуарів нівелюється доступною проїзною зоною. Крім того, важливим доповненням до системи міського транспорту стала мережа маршрутних таксі, яка хаотично сформувалася в умовах ринку.

Перелічені негативні зміни виникли внаслідок відсутності ефективної програми міського планування та управління громадським транспортом. Досить сказати, що за будівництво доріг, функціонування системи наземного транспорту та містобудування відповідають різні підрозділи Міської адміністрації (Управління дорожнього господарства, Управління капітального будівництва, Управління державного архітектурно-будівельного контролю, управління інженерного захисту території міста та розвитку узбережжя) [9].

Ціллю статті є систематизація основних проблем транспортної інфраструктури міста та опис сутності проектів, необхідних для їх вирішення.

Основний матеріал дослідження. Аналіз статистичної інформації, збір матеріалів у різних періодичних джерелах, а також вивчення Генерального плану Одеси [10] та інших нормативних документів, дозволив виділити сім найбільш значущих категорій транспортних проблем Одеси, що існують на даний момент.

1. Недостатня кількість дорожніх об'єктів для зв'язку центральної частини міста 3 мікрорайонами.

Проблема транспортної комунікації між центральною частиною Одеси та «спальними районами» $є$ однією з найважливіших для розвитку міста. На склад транспортної інфраструктури Одеси мали вплив політичні, економічні та культурні процеси, а темпи розвитку міста постійно змінювалися. Одеса в контурах іiі центру є одним з небагатьох міст, побудованих за планом, який передбачав геометрично правильну вуличну 
ВІСНИК

ОДЕСЬКОГО НАЦІОНАЛЬНОГО МОРСЬКОГО УНІВЕРСИТЕТУ № 3 (60), 2019
HERALD

OF THE ODESSA NATIONAL MARITIME UNIVERSITY № 3 (60), 2019

забудову, відповідно до правила спрямування вулиць від моря за найкоротшими відстанями. Однак з плином часу, через різні чинники, будівництво все дальше відходило від закладеної регулятивної ідеї.

В основі розташування міста лежить проект, який передбачав будівництво двох прямокутних сіток кварталів, які стикуються під 45-градусний кут в районі вулиці Преображенської. Проектом також вдалося розвести за рівнями порт і міську зону. У плані малося на увазі існування широкої транспортної осі від моря, через Військову балку і далі через проспект, що пронизував все місто. Однак, аналогу Єлисейських полів - Олександрівському проспекту - не судилося 3'ясуватися в повному обсязі, завдяки так званим «круглим будинкам». Спочатку було продано, а потім видано дозволи на будівництво надзвичайно перспективних ділянок землі навколо вулиці Грецької. Треба сказати, що навіть тоді проблема інфраструктури з'явилася в локальному масштабі. У міста не було коштів, щоб викупити раніше продані ділянки для масштабного будівництва бульварів.

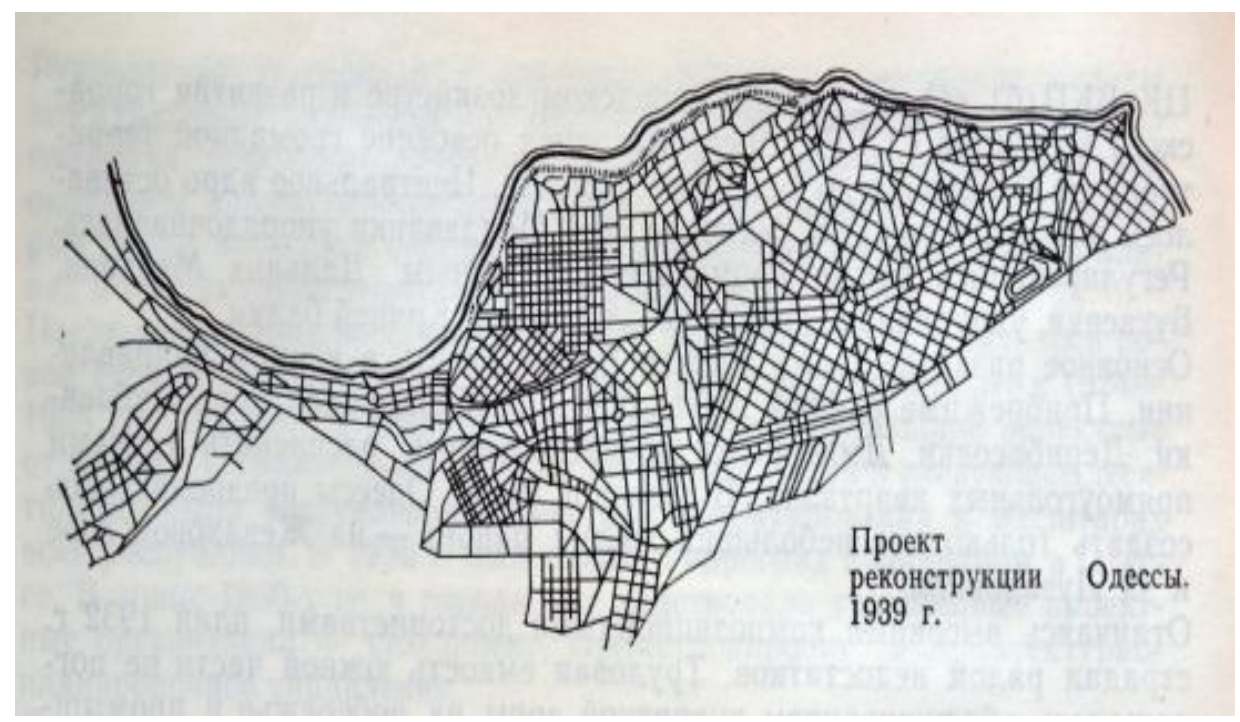

Рис. 1. Проект реконструкиії міста 1939 р. [11]

Під час Першої світової та Громадянської війн кількість населення Одеси зменшилася вдвічі, а розвиток практично повністю припинився. До 1941 р. вдалося реалізувати лише 10 \% планів нового генерального плану, який передбачав розширення житлових зон на Фонтан, Чубаївку, Лузанівку, Аркадію і концентрацію промисловості на Пересипі і Бугаєвці (рис. 1). У зв'язку з тим, що Одеський порт вичерпав можливості територіального розвитку, було спроектовано новий порт на Сухому Лимані. 
Після 1945 р. реальним планам впровадження широких транспортних артерій міста запобіг катастрофічний дефіцит житла, в умовах якого знесення значної кількості будівель було неможливим, але за іншими напрямками плану робота тривала. Були створені нові мікрорайони на заздалегідь спланованих ділянках. Крім південного напрямку (селище Таїрова), робота проводилася в північному напрямку, де з'явилося селище Котовського. Особливість його розташування була обумовлена генпланом 1965 р., яким були передбачено, що в подальшому орієнтовна чисельність населення цього селища досягне 100 тис. осіб, а потім воно буде виділено в окреме місто-супутник.

Передбачалося, що більшість населення селища буде зайнята на підприємствах нового промислового вузла, що формувався в районі Центроліта, в проектованому порту на Аджаликському лимані, а також заводах Пересипу. У складі транспортної інфраструктури було побудовано Об'їну дорогу, був підготовлений великий проект магістралі «Північ-Південь», що з'єднував вулиці Фрунзе (Балківську) і Якіра (Іцхака Рабіна) підземними тунелями (рис. 2), а так само метро. Однак пізніше прийшла епоха застою, коли обмежувались проектами багаторівневих розв'язок і освоєнням території існуючого приватного сектора, які теж не було реалізовано з огляду на перехід до ринкової економіки.

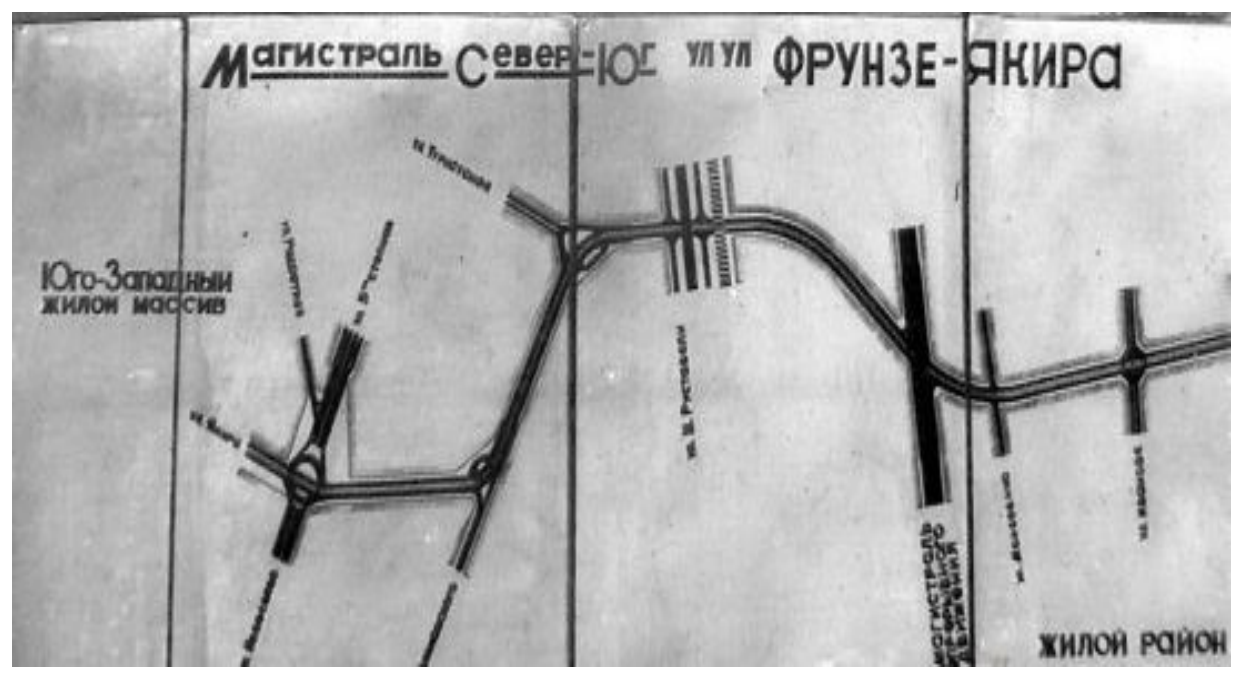

Рис. 2. Фрагмент Генплану міста другої половини ХХ $\mathrm{cm}$.

Всі плани радянських часів вважали Одесу за багатофункціональне місто - промислове, транспортне, курортне, наукове, освітнє, але жодним чином не комерційне. У міста не було коштів у відносно благополучні 1970-1980-і рр. для траси «Північ-Південь», розв'язок, метро або, принаймні, швидкісного трамваю [11]. 
Зараз можна бачити, що значна концентрація місць праці громадян, що проживають в Одесі, так званого «центрального типу» (офіси, магазини, ресторани і т. д.), спостерігається в певних районах міста. Вони приваблюють значну кількість людей 3 інших районів. В результаті, в день міграційна напруга на центр, який виконує як стикувальну, так $\mathrm{i}$ соціальну функцію, значно збільшується за рахунок жителів «спальних районів». Це створює ефект вузького «пляшкового горла» на з'єднувальних об'єктах між районами і центром (мостах, складних перехрестях).

У нинішньому Генеральному плані $є$ ряд позитивних моментів високошвидкісний позавуличний транспорт, багаторівневі розв'язки і нові дороги, - але, судячи з реальної ситуації останніх двох десятиліть, розвиток наземної транспортної інфраструктури реально буде проходити дуже повільно і не зможе вирішити існуючі проблеми в швидкий термін.

2. Відсутність розвитку «хайвеїв» міста.

Швидка автомобілізація, розвиток передмість, зростання дачного та котеджного будівництва, доповнені збільшенням пасажиропотоку автомобільних перевезень, які стимулюються ринковими і соціальними перетвореннями пострадянського часу, призвели до значного збільшення руху маятникових міграцій і загального збільшення потоку між Одесою та Одеською областю.

В результаті спостерігається наявність всього двох швидкісних магістралей, які на даний момент не $\epsilon$ насправді такими через забудову прилеглих до них територій і наявності великої кількості світлофорів. На потокових напрямках виїзду на траси міжміського призначення, а також на окружні дороги, які спрямовані надати альтернативу перевантаженим внутрішнім дорогам міста, виникають регулярні затори, особливо в напружені літні вихідні дні.

Заходи, розпочаті ще в радянські часи, були заморожені, і роботи по створенню «хайвеїв» відсутні. Зараз функціонує дорога, яка виходить на Київське шосе через «Конюшинний міст» та дворівневу розв'язку в районі автовокзалу, яка насправді за планами повинна була перетворитися в перший «хайвей». Дорога Тираспольського шосе з вулиці Столбова переривається круговим рухом Двох Стовпів, хоча район Застави-2 має дворівневу розв'язку, яка нівелюється завантаженим залізничним переїздом Дальницького шосе.

У той же час, Овідіопольська дорога виконувати призначення як магістраль взагалі нездатна через круговий рух на стику з Об'їзною дорогою, а від запланованої траси від Овідіопольської дороги до селища Таїрова повністю відмовилися при іiі готовності в $25 \%$. 3 огляду на наявність двох лиманів, що звужують можливості розвитку Миколаївського напрямку, дороги тут проходять через вже перевантажене селище Котовського. Місця можливих розширень кількості магістралей показані в новому Генеральному плані [10]. 
ВІСНИК

ОДЕСЬКОГО НАЦІОНАЛЬНОГО

МОРСЬКОГО УНІВЕРСИТЕТУ

№ 3 (60), 2019
HERALD

OF THE ODESSA NATIONAL

MARITIME UNIVERSITY № $3(60), 2019$

3. Недостатня розвиненість сполучних елементів інфраструктури між центрами зародження транспортних потоків.

Ця проблема викликана наявністю в центрі залізничного вокзалу і порту та відповідних залізничних/автодорожніх маршрутів, що ведуть ззовні. Це пов'язано з тим, що дані об'єкти вони були закладені ще на початку XX століття. 3 часом зростаюче місто заповнило вільні простори навколо залізничних трас та портової зони.

Зусилля влади радянських часів пом'якшили цю проблему, але, як згадувалося раніше, через перехід до ринкової економіки, більшість проектів так і не було реалізовано. Це стосується й аеропорту, який на той час був аеровокзалом і тільки з швидким розвитком повітряних сполучень одержав статус міжнародного. 3 меж міста аеропорт планувалося вивести; його розташування негативно позначається на пропускній спроможності вулиць, що охоплюють аеропорт по периметру [11].

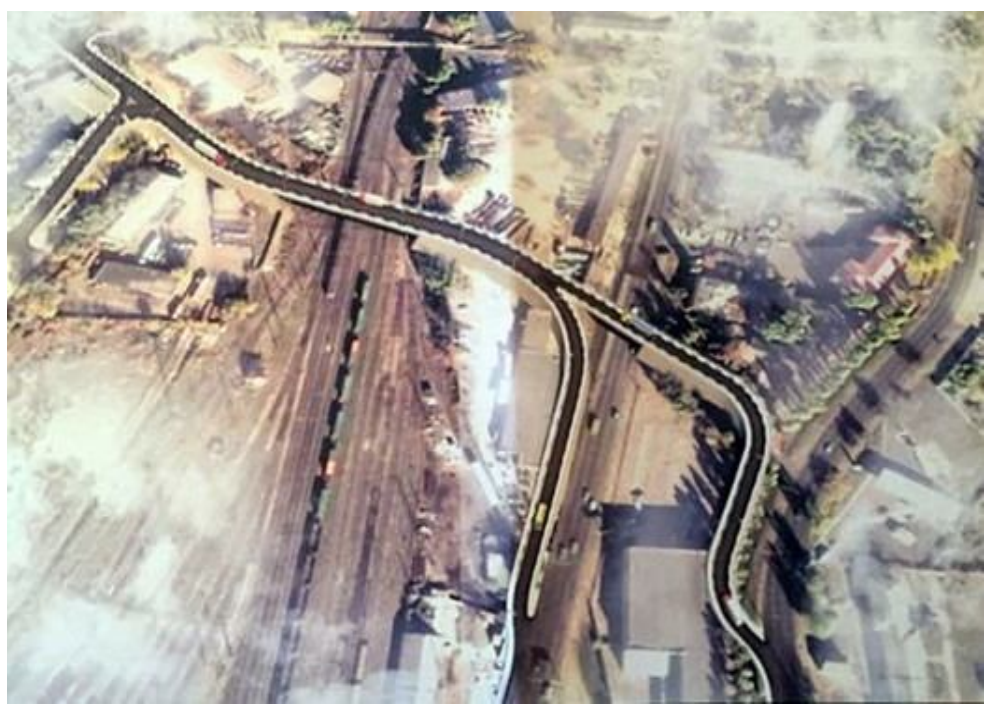

Рис. 3. Проект автотраси Хаджибей-2

Місцями можливих шляхопроводів можуть бути як тунелі, так i мости, наприклад, на вулиці Чернишевського, а також розширення існуючих шляхопроводів Пересипського мосту, Передпоромної, Тираспольського шосе. Крім того, можливе проведення магістралей безпосередньо через аеропорт під злітно-посадковою або маневровою смугою у зв'язку з поточною роботою над їх оновленням. Що стосується порту, заплановано будівництво двох доріг для з'єднання Об'їзної дороги з Євротерміналом і Морським портом паралельно Хаджибеївській дорозі або для іiі доповнення (рис. 3). Будівництво пропонується здійснювати власними коштами ТОВ «Евротермінал» та ДП «Адміністрація морських портів України» [12]. 
4. Обмежені можливості для руху і паркування автомобілів в центральній частині міста.

Як уже було відмічене вище, в центральній частині міста розташована значна кількість місць притягнення населення (офіси установ та різноманітних фірм, навчальні заклади, багато магазинів, ресторанів, кафе, інших сервісних установ). У зв'язку з цим в Одесі характерні щоденні маятникові переміщення населення 3 віддалених (спальних) районів до центру міста. Існуюча дорожня мережа не справляється 3 напливом транспортних засобів, затори стали звичайним явищем. Це також стосується районів, в яких спостерігається зверхщільна висотна забудова житловим фондом в останні роки. Відсутність координації та планування з боку міської влади та забудовників призвело до перевантаження вулиць та вуличних розв'язок, пропускна спроможність яких не відповідає потокам таких переміщень. Подібну ситуацію можна спостерігати, наприклад, на вулицях Генуезькій, Левітана, Маршала Говорова. Гостро стоїть питання як денного, так і нічного паркінгу автомобілів [13].

Можливості розширення вулично-дорожньої мережі в центральній частині та в районах щільної забудови практично повністю відсутні через те, що велика частина міста є єдиним пам'ятником архітектури, що входить до складу матеріалів, представлених на розгляд Всесвітньої культурної та природної спадщини ЮНЕСКО з одного боку, та межами приватних володінь, з іншого [14].

Багато об'єктів центральної частини міста віднесено до зон захисту об'єктів культурної спадщини. У таких умовах зменшити потік транспортних засобів в центрі міста і оптимізувати умови паркування в щільно забудованих районах здається, можливо, в першу чергу, обмежуючи паркування. Експертами вважається найбільш обгрунтованою така міра, як організація досить широких зон платних стоянок за досвідом міст розвинених країн. Але, як це вже видно на прикладі підземного паркінгу на Грецькій площі, на цільове призначення таких проектів впливають перш за все фактори ринкових відносин, що ставить під сумнів успішну реалізацію.

Тим не менш, набагато більш розумним рішенням може бути переробка системи штрафів за неналежне паркування і введення більш жорстких правил або стимулювання відмови від використання особистого транспорту. Незалежно від шляху подальшого розвитку, зрозуміло, що воно повинно супроводжуватися паралельним активним розвитком громадського транспорту, поліпшенням якості його роботи, розвитком велосипедної та пішохідної інфраструктури, а також поза вуличного транспорту.

5. Відсутність розвитку системи невуличного транспорту.

В умовах великого завантаження вулично-дорожньої мережі автотранспортом хіба чи не єдиною альтернативою автомобілю може бути розвиток системи громадського транспорту i, перш за все, - 
ВІСНИК

ОДЕСЬКОГО НАЦІОНАЛЬНОГО МОРСЬКОГО УНІВЕРСИТЕТУ № 3 (60), 2019
HERALD

OF THE ODESSA NATIONAL

MARITIME UNIVERSITY № 3 (60), 2019

позавулич-ного (до таких видів транспорту традиційно відносяться метрополітен, легкі залізниці, монорейку, швидкісний трамвай, «морський трамвай»). Проект Одеського метрополітену [11], ймовірно, залишиться невиконаним назавжди, хоча 3 розгалуженою системою підземки від селища Котовського і до селища Таїрова можна було б розвантажити більшість центрів скупчення наземних транспортних засобів. Запропонований варіант швидкісного трамваю, що зв'язує два діаметрально віддалених райони міста, навряд вирішить проблему через знаходження колії безпосередньо на проїзній частині вулиці Преображенської, якому немає альтернативи на даний момент [15].

3 огляду на географічне розташування Одеської затоки, логічною пропозицією є відновлення послуги «морського трамвайного» сполучення. За радянських часів прибережний сервіс обслуговування катерами охоплював все Одеське узбережжя з Лузановки до Чорноморки. Завдяки можливості побувати в морі, побачити узбережжя, а також через низьку вартість (менше 1 рубля), «морські трамваї» (рис. 4) були дуже популярні. Однак згодом, через вихід зі строю причальних комплексів за межами Одеського порту, морські прогулянки стали можливими тільки з самого порту. Тому, зберігаючи прогулянкову компоненту, роль катерів як транспортних засобів для перевезень пасажирів була втрачена. Однак зараз старт такого проекту за умови державної підтримки цілком можливий. Робота в цьому напрямі проводилася в 2015 р., планувалося встановити тимчасові плаваючі причали і використовувати 5 катерів, що знаходилися у розпорядженні морського порту [16].

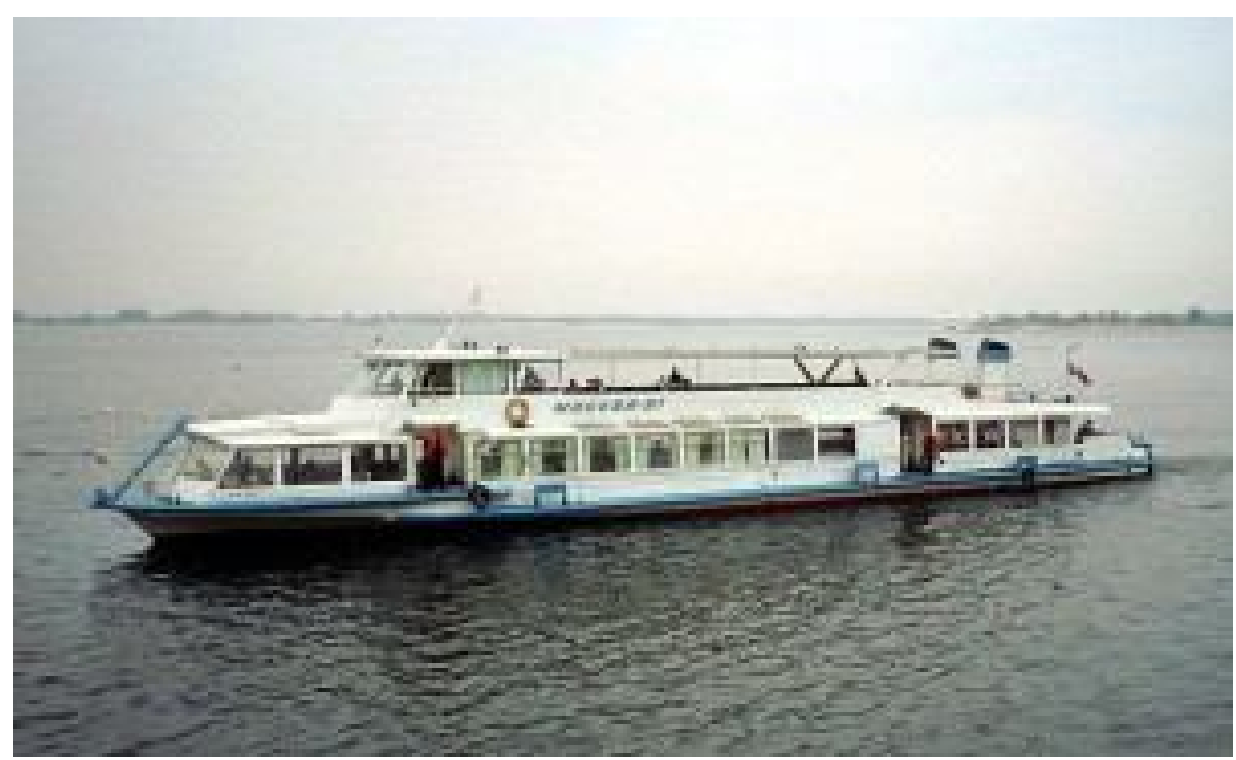

Рис. 4. Морський трамвай 
6. Відсутність міської мережі велодоріжок.

В даний час явно недооціненою $€$ можливість використання велосипеда або його аналогів як транспортних засобів. Для велосипедистів у центрі міста майже немає виділених доріжок. Хоча у великих і густо забудованих містах Європи, де, як і у нас, $є$ зміни погодних умов від сніжної зими до спекотного літа, велосипед і його аналоги вже давно стали важливим транспортним засобом. Зокрема, в деяких європейських містах, таких як, наприклад, Копенгаген, велосипедні доріжки зводяться навіть за умови зменшення розміру пішохідної частини вулиць. На даний момент, з числа запропонованих, реалізовано лише декілька можливих маршрутів. Так реалізована велосипедна доріжка між провулком Нахімова i Аркадією, розмічений тротуар на вулицях Краснова і Довгій. Також, велика кількість прогулянкових велосипедних доріжок $є$ у всіх парках Одеси. Однак, цей стан справ не сприяє вирішенню транспортних проблем міста і його слід оцінювати як лише перші кроки для подальшого поширення велодорожної мережі та ii урахування у Генеральному плані міста 3 огляду на викладені фактори.

7. Відсутність сучасного громадського транспорту, що зв'язує міські райони з аеропортом і Промисловим ринком.

У сучасних умовах аеропорти $є$ важливими елементами транспортної інфраструктури будь-якого великого міста. В міжнародному аеропорту Одеси, який в 2015 р. проходив реконструкцію, побудований новий термінал 3 проектною місткістю 1000 пасажирів на годину. На даний момент оновлена злітно-посадкова смуга готова на $40 \%$. Оскільки пасажиропотік має стабільну динаміку зростання, планується до 2040 p. збільшити пасажиропотік до 5 млн. осіб за рік [17]. Однак, на даний момент, дістатися до аеропорту можна тільки тролейбусом 14 маршруту, який проходить від залізничного вокзалу через завантажені центральні вулиці міста і промислові райони, далі по Овідіопольській дорозі або на таксі і приватному транспорті по вузьким сусіднім вулицям Радісній і Кострова.

Недалеко від аеропорту знаходиться найбільший оптово-роздрібний ринок України та Свропи, загальною площею 75 га і з відвідуванням 250000 осіб на добу. На Промисловий ринок організований в'їзд та виїзд з 10 сторін по периметру ринку; на додаток до приватних автомобілів на ринок прибувають автобуси та мікроавтобуси з усіх міст України щодня. Тільки з Одеси на ринок щоденно йдуть 30 постійних маршрутів автомобільного транспорту [18], що впливає на завантаження транспортного сполучення Овідіопольської дороги.

Вирішенням проблеми, а також способом підвищенням комфорту пересування пасажирів може стати створення нової лінії позавуличного транспорту - залізничного експресу за аналогією з проектами інших міст, але не тільки для з'єднання з аеропортом, але й Промисловим ринком. Така траса може бути створена на базі вже існуючої залізниці: Одеса- 
Головна-Одеса-Західна. За пасажиромісткістю залізничний експрес має набагато більші можливості, ніж автотранспорт. Крім того, інфраструктура частково готова: залізнична станція Одеса-Західна знаходиться між Промисловим ринком та Міжнародним аеропортом Одеси.

Висновки. Підводячи підсумки розгляду існуючих транспортних проблем Одеси, слід зазначити, що їх можна систематизувати по наступних сімох групах: недостатня кількість дорожніх об'єктів для зв'язку центральної частини міста 3 мікрорайонами; відсутність розвитку швидкісних магістралей; недостатня розвиненість сполучних елементів інфраструктури між центрами зародження транспортних потоків; обмежені можливості для руху і паркування автомобілів в центральній частині міста; відсутність розвитку системи невуличного транспорту та міської мережі велодоріжок; відсутність сучасного громадського транспорту, що зв'язує міські райони з аеропортом і Промисловим ринком. Описані проблеми постають основою для ініціювання проектів, спрямованих на їх вирішення.

3 огляду на географічне розташування міста, досвід останніх десятиліть XX ст. та повернення уваги до відродження морських прибережних перевезень недавнього періоду, логічною пропозицією серед проектів розвитку системи невуличного транспорту є відновлення послуг морського прибережного сполучення. Супутньою до збереження та поширення прогулянкової компоненти метою $є$ використання пасажирських суден прибережної зони плавання саме як транспортних засобів для перевезень пасажирів. Від якості та розвиненості транспортної інфраструктури, зручності та комфорту міських транспортних сполучень для мешканців і гостей нашого міста залежить подальший стан економіки міста i регіону в цілому.

\section{СПИСОК ЛІТЕРАТУРИ}

1. City population, UN: веб-caüm. URL: http://data.un.org/ (dama звернення: 24.09.2019).

2. Statistical Data. The World Bank Group: веб-caŭm. URL: https://www.worldbank.org/ (дата звернення: 24.09.2019).

3. Рост Количества Автомобилей. AutoConsulting. Информационно Аналитическая Групna. URL: http://www.autoconsulting. сот.иа (дата звернення: 24.09.2019).

4. Лапкін О.О. Логістичний аспект проекту транснаціональної доставки автомобілів / Проектний та логістичний менеджмент: нові знання на базі двох методологій. Том 2: монографія// [авт. кол.: І.О. Лапкіна, В.О. Андриєвська, В.Ю. Смрковська та ін.]. Одеса: КУПРИСНКО СВ, 2019. С. 170178. 
ВІСНИК

ОДЕСЬКОГО НАЦІОНАЛЬНОГО

МОРСЬКОГО УНІВЕРСИТЕТУ

№ 3 (60), 2019
HERALD

OF THE ODESSA NATIONAL

MARITIME UNIVERSITY

5. Петухов В.С. Организация морских пассажирских перевозок в местном сообщении. М: Изд-во Транспорт, 1970. 152 c.

6. Басевич В.В. Организация морских пассажирских перевозок. М: Изд-во Траспорm, 1972. $208 \mathrm{c}$.

7. Шибаев А.Г. Пассажирские перевозки / А.Г. Шибаев, Г.Н. Сильванская, И.М. Петров; под общ. ред. д.т.н., проф. А.Г. Шибаева. Одесса: Феникс, 2013. 336 с.

8. В Одессе около путепровода «Поездной» вводят одностороннее движение. URL: https://traffic.od.ua/news/dorogi/1197001 (дата звернення: 21.11.2019).

9. URL: https://omr.gov.ua/ua/city/offices/ (дата звернення: 24.09.2019).

10. Генплан Одеси. URL: http://old.omr.gov.ua/images/ File/ DODATKI_2015/Arhitektura/Gen_plan_osn.zip (дата звернення: 24.09.2019).

11. Вельможко А., Ларин Н. Старые Генпланы Oдессы. URL: https://dumskaya.net/news/starye-genplany-kak-hrust-francuzskojbulki-ne-s-027475/ (дата звернення: 27.11.2019).

12. АМПУ предлагает новое решение проблемы проезда грузовиков в Одесский nopm. URL: http://ports.com.ua/news/ampupredlagaet-novoe-reshenie-problemy-proezda-avtotransporta-vodesskiy-port (дата звернення: 24.09.2019).

13. Вельможко А. Одесса: Аркадия и Фонтан с высоты квадрокonmepa. URL: https://www.youtube.com/watch? time_continue= $33 \& v=y 0 w g z q a P 9 Z M$ (дата звернення: 24.09.2019).

14. Досье для ЮНЕСКО. URL: https://ru.espreso.tv/news/2018/ 12/15/yunesko_poluchyt_quotdosequot_na_odessu

(даma звернення: 24.09.2019).

15. Трамвай Север-Юг. URL: https://traffic.od.ua/news/eltransua/ 1213202 (дата звернення: 24.09.2019).

16. Морской трамвай. Новая Жизнь. URL: https://www.youtube. com/watch? $v=D$ s $7 T 17 N x r i U$ (дата звернення: 24.09.2019).

17. Міжнародний Aеропорт Oдеса. URL: http://www.odessa.aero/ (дата звернення: 24.09.2019).

18. Промтоварный рынок «7км». URL: http://www.7km.net/ (dama звернення: 24.09.2019).

\section{REFERENCES}

1. City population, UN. URL: http://data.un.org/(date of reference: 24.09.2019).

2. Statistical Data. The World Bank Group. URL: https://www. worldbank.org/ (date of reference: 24.09.2019). 
ВІСНИК

ОДЕСЬКОГО НАЦІОНАЛЬНОГО

МОРСЬКОГО УНІВЕРСИТЕТУ

№ 3 (60), 2019
HERALD

OF THE ODESSA NATIONAL

MARITIME UNIVERSITY

3. Rost Kolichestva Avtomobiley. AutoConsulting. Infirmatsionno Analiticheskaya Gruppa. URL: http://www.autoconsulting.com.ua (date of reference: 24.09.2019) [in Russian].

4. Lapkin O.O. (2019) Logistichniy aspect proektu transnatsional'noi dostavki avtomobiliv (The logistic aspect of the transnational car delivery project / Proektiy ta logistichniy menedzhment: novi znannya na bazi dvoh metodologiy (Project and logistics management: new knowledge based on two methodologies) // [I.O. Lapkina, V.O. Andrievskaja, V.U. Smrkovskaja and oth.]. Vol. 2. Monograph. Odesa: KUPRIENKO SV. 170-178 [in Ukrai-nian]. DOI: 10.21893/2616-8936.2019-02.

5. Petuhov V.S. (1970) Organizaciya morskih passazhirskih perevozok $v$ mestnom soobschenii (Organization of maritime passenger transportation in local communication). M: Transport. 152 [in Russian].

6. Basevich V.V. (1972) Organizaciya morskih passazhirskih perevozok (Organization of maritime passenger transportation). M: Transport. 208 [in Russian].

7. Shibaev A.G. (2013) Passazhirskije perevozki (Passenger transportation) / A.G. Shibaev, G.N. Sil'vanskaja, I.M. Petrov. Odessa: Feniks. 336 [in Russian].

8. V Odesse okolo puteprovoda "Poeznoi» vvodjat odnostoronnee dvizhenie (In Odessa near the overpass « Poeznoi» one-way traffic was presented). URL: https://traffic.od.ua/news/dorogi/1197001 (date of reference: 21.11.2019) [in Russian].

9. URL: https://omr.gov.ua/ua/city/offices/ (date of reference: 24.09.2019) [in Ukrainian].

10. Genplan Odesy (The General Plan of Odesa). URL: http://old. omr.gov.ua/images/File/DODATKI_2015/Arhitektura/Gen_plan_o sn.zip (date of reference: 24.09.2019) [in Ukrainian].

11. Vel'mozhko A., Larin N. Starije Genplani Odessy. (Old General Plans of Odessa) URL: https://dumskaya.net/news/staryegenplany-kak-hrust-francuzskoj-bulki-ne-s-027475/ (date of reference: 27.11.2019) [in Russian].

12. AMPU predlagaet novje reshenie problem proezda gruzovikov $v$ Odesskij port (AMPU offers a new solution to the problem of truck routs to the Odessa port). URL: http://ports.com.ua/news/ampupredlagaet-novoe-reshenie-problemy-proezda-avtotransporta-vodesskiy-port (date of reference: 24.09.2019) [in Russian].

13. Vel'mozhko A.. Odessa: Arkadija i Fontan s visoti kvadrokoptera (Odessa: Arcady and Fontan from the height of quadcopter). URL:https://www.youtube.com/watch? time_continue $=33 \& v=y 0 \mathrm{wg}$ zqaP9ZM (date of reference: 24.09.2019) [in Russian]. 
ВІСНИК

ОДЕСЬКОГО НАЦІОНАЛЬНОГО

МОРСЬКОГО УНІВЕРСИТЕТУ

№ 3 (60), 2019
HERALD

OF THE ODESSA NATIONAL

MARITIME UNIVERSITY

№ $3(60), 2019$

14. Dos'je dlja UNESCO (Dossier for UNESCO ). URL: https://ru.espreso.tv/news/2018/12/15/yunesko_poluchyt_quotdose quot_na_odessu (date of reference: 24.09.2019) [in Russian].

15. Tramvaj «Sever-Ug» (The tram «North-South»). URL: https:// traffic.od.ua/news/eltransua/1213202 (date of reference: 24.09.2019) [in Russian].

16. Morskoj tramvaj. Novaja zhizn' (Sea tram. The new life). URL: https://www.youtube.com/watch? $v=D$ s $7 T 17 N x r i U$ (date of reference: 24.09.2019) [in Russian].

17. Mizhnarodnij Aeroport Odesa (Odesa International Airport). URL: http://www.odessa.aero/ (date of reference: 24.09.2019) [in Ukrainian].

18. Promtovarnij rinok «7km» (The Industrial market «7km»). URL: http://www. 7km.net/ (date of reference: 24.09.2019) [in Russian].

Стаття надійшла до редакиії 26.11.2019 